\title{
Vegetation of Abandoned Fields on Soil Types of Kastanozems in Northern Kazakhstan (Kostanay Region)
}

\author{
Tilepbergen Ryspekov', Jiří Jandák², Marzhan Balkozha', Jan Winkler ${ }^{3 *}$ \\ 1 Department of Soil sciences and agro chemistry, Non-profit Corporation Kazakh National Agrarian \\ University, Abay 8, 050010, Almaty, Kazakhstan \\ 2 Department of Agrochemistry, Soil Science, Microbiology and Plant Nutrition, Faculty of AgriSciences, \\ Mendel University in Brno, Zemědělská 1, 61300 Brno, Czech Republic \\ ${ }^{3}$ Department of Plant Biology, Faculty of AgriSciences, Mendel University in Brno, Zemědělská 1, \\ 61300 Brno, Czech Republic \\ * Corresponding author's e-mail: winkler@mendelu.cz
}

\begin{abstract}
This study provides original data on the impact of human activity on vegetation under the specific conditions of the Kastanozem from the Kostanay region (northern Kazakhstan). Radical changes in land use are provoking deposition in vegetation. The question remains whether natural vegetation will return or whether a different type of vegetation will be created under the specific conditions of the Kastanozems soils. The evaluation of vegetation took place in the fields that were abandoned in different time horizons. Height, cover, biomass weight and species composition of vegetation were monitored. The vegetation of abandoned fields is characterized by low species diversity. Succession runs from annual species to a stage where perennial dicotyledonous species with a deep root system dominate. Spontaneous vegetation leaves a sufficient amount of biomass on the soil surface, which assumes that the land will be protected from undesirable phenomena such as erosion and desertification processes.
\end{abstract}

Keywords: abandoned fields, Kastanozems, succession vegetation, Kazakhstan

\section{INTRODUCTION}

Kazakhstan experienced the most considerable anthropogenic land cover change in the twentieth century. During the 'Virgin Lands Campaign', about $420000 \mathrm{~km}^{2}$ of temperate grassland, mainly in northern Kazakhstan and in the Altai region of Russia, were converted into arable land for grain production (Frühauf et al., 2020; Prishchepov et al., 2020).

Large areas of arable land were abandoned after the collapse of the Soviet Union in 1991 (Rachkovskaya and Bragina, 2012). According to Espolov (2002), only the sown area of grain crops from 1995 to 1999 decreased from 18.88 million hectares to 11.39 million hectares, which is more than 7 million hectares. The reasons for this situation are expressed by the fact that there are difficulties associated with an irrational and inefficient use of agricultural land (Nyussupova et al., 2015). However, Akiyanova et al. (2014) and Kazangapova et al. (2017) reported that land degradation is still observed in a significant territory of the Republic of Kazakhstan.

Land degradation and its manifestation in drylands, known as desertification, are the most critical environmental issues in many parts of the world (Fleskens and Stringer, 2014; Kouba et al., 2018; Kirichenko-Babko et al., 2020; Schwieger and Mbidzo, 2020; Wijitkosum, 2021). Kazakhstan, a typical country, is suffering from severe desertification risks (Hu, Han, Zhang, 2020). Several necessary changes in agriculture and animal husbandry may result in desertification moving in different directions, such as the expansion of irrigated agriculture and the abandonment of extensive croplands, the collapse of animal husbandry, and the abandonment of distant pastures (Klein et 
al., 2012; Xi and Sokolik, 2016). Wind erosion is a global environmental issue (Dudiak et al., 2020; Kučera et al., 2020; Zhang et al., 2021), affecting approximately one-third of the world's land, including Central Asia (Pimentel et al., 1995; Shen et al., 2018). Reportedly, the average soil wind erosion rate reaches $4000 \mathrm{t} \cdot \mathrm{km}^{-2}$ in Central Asia (Barrow, 1991). In central and western Kazakhstan, ecological engineering measures, such as green barriers, should be established to prevent soil loss during the 21 st century (Li et al., 2020).

In the past, it was common to temporarily leave pastures, which were used to restore the pasture fertility (Shevynogov et al., 2019). However, this has not happened on such a scale as at present. Abandoned fields are mainly in the area with the Kastanozems soil type. In Kazakhstan, the area of Kastanozems soils of the dry steppe subzone is 20.7 million hectares; in agricultural land, 10.2 million hectares are registered. The area of arable land, as of 1 November 2015 is 1785.6 thousand hectares (Uspanov et al., 1975; Anonym 2016).

The use of land for agricultural production has led to a change in the upper layers of the soil (Klatka, 2020; Qin et al., 2020), which are more homogenized than if they were in their natural state. However, the conversion of natural grasslands into croplands is usually accompanied by significant changes in vegetal biomass, soil physical characteristics, and carbon and nutrient contents, leading to corresponding changes in carbon and nutrient stocks and their stoichiometric ratios. Derived croplands are characterized by considerable external inputs and outputs of carbon as well as nutrients via fertilizer application and crop harvest (Kanchikerimath and Singh, 2001; Li et al., 2009). The abandonment of croplands and subsequent natural restoration into abandoned lands can commonly lead to the accumulation of plant biomass in the soil, engendering the relatively closed carbon and nutrient cycles (Richard et al., 2001; Vesterdal et al., 2002; Davidson et al., 2007).

The specific characteristics of Kastanozem are unsatisfactory for the growth of most species of herbs, shrubs, and trees (Kalinichenko, 2015). Long-term abandonment leads to the changes in species composition, vegetation structure and causes diversity losses (Enyedi et al., 2008). Still, there is a serious lack of data regarding the dynamics and restoration prescriptions for these abandoned drylands (Cremene et al., 2005).
Radical changes in land use are provoking deposition in vegetation. The question remains whether there will be a return of natural vegetation or whether a different type of vegetation will be created under the specific conditions of Kastanozems soils. The study aims to assess the development and characterize vegetation composition in abandoned, unused fields with soil type Kastanozems. Furthermore, the possibilities of vegetation biomass to protect soil quality were evaluated. The study set the following subobjectives (i) determine the type of vegetation in abandoned fields; (ii) determine the effect of land non-use time on vegetation; (iii) assess the effect of non-use time on phytomass on the soil surface.

\section{MATERIAL AND METHODS}

This study was conducted in the area of northern Kazakhstan in the Kostanay region. Temporarily unused fields at Arkalyk Agricultural Experimental Station (AAES) were selected for monitoring. A specific soil type Kastanozem is represented in the area (IUSS Working Group WRB, 2015). The Kastanozem is moderately thick; the soil profile occurs at $0.4-0.6 \mathrm{~m}$ depth. The soil organic matter (SOM) content is $2.6 \%$. Granulometric properties are $47.7 \%$ physical clay and $29.5 \%$ clay. The $\mathrm{CaCO}_{3}$ content is $0.15 \%$ (up to $3-10 \%$ at $0.8-1.5 \mathrm{~m}$ soil depth). The $\mathrm{pH}$ value is 7.8 .

The climatic and meteorological data from the "Arkalyk" meteorological station were used; the data were taken from the period of 1986 to 2006. Significant differences in temperature during the year are typical for the monitored area. The average air temperature is $3.5^{\circ} \mathrm{C}$, large differences between temperatures are typical. The coldest month is January. The average air temperature is $-19^{\circ} \mathrm{C}$. The warmest month is July; the average air temperature is $21^{\circ} \mathrm{C}$. The average soil surface temperature is $44.4^{\circ} \mathrm{C}$ in June, $45.7^{\circ} \mathrm{C}$ in July and $42.0^{\circ} \mathrm{C}$ in August. Rainfall is highly uneven. In the summer months of 1992 and 1993, total precipitation amounted to $117.88 \mathrm{~mm}$ and $143.26 \mathrm{~mm}$, respectively. In 1997, only $7.31 \mathrm{~mm}$ was recorded during the summer.

Vegetation assessment took place on the land originally used for growing spring wheat. In order to evaluate the course of vegetation succession, the fields that were abandoned in different time horizons were selected. The Global Positioning 
System (GPS) coordinates are given in Table 1 and Figure 2. Four fields have been selected:

- Field No35A: the land ceased to be used for agriculture in 2016, left fallow for 2 years (Fig. 1a),

- Field No12: the land ceased to be used for agriculture in 2015, left fallow for 3 years (Fig. 1b),

- Field No7: the land ceased to be used for agriculture in 2014, left fallow for 4 years (Fig. 1c),

- Field No59: the land ceased to be used for agriculture in 2012, left fallow for 6 years (Fig. 1d).

Evaluation of vegetation was performed using phytocenological relevés. Four phytocenological relevés were randomly plotted in each monitored field. The size of one relevés was $25 \mathrm{~m}^{2}$. In each image, all plant species were determined. The total cover of living vegetation and the cover of individual plant species were estimated. The maximum stand height was measured. The coverage was defined directly as a percentage, and the size was measured in meters. The evaluation deadline was June 2018 and 2019.

Phytomass determination was executed on the areas near phytocenological relevés. The sampling area of $1 \mathrm{~m}^{2}$ in 4 repetitions was marked out. All plants were pulled up from each sampling area, and phytomass was collected. The phytomass was placed in paper bags, dried and weighed in the laboratory, and converted to $\mathrm{t} \cdot \mathrm{ha}^{-1}$. The vegetation survey was performed in June 2018.

The determined values of total cover, maximum stand height and phytomass weight were statistically processed and evaluated using the Statistica program (version 12). Analysis of variance (ANOVA) was applied, and the method of minimal detection difference (Fisher's LSD test) was chosen for subsequent testing.

Multivariate analyses of ecological data processed the data recorded from phytocenological relevés. First, a Detrended Correspondence Analysis (DCA) was performed, which led to calculating of the Lengths of Gradient. Subsequently, a Redundancy Analysis (RDA) was used. Proof testing was performed using the Monte-Carlo test, and a total of 999 permutations were calculated. Computer program Canoco 5.0. was used to process data and calculations.

\section{RESULTS AND DISCUSSION}

The processed and statistically analyzed results of monitored vegetation characteristics (total cover, maximum stand height, biomass weight) are given in Tables 2 and 3. The obtained results show a significant influence of the year on the height of the stand and the cover. The influence of the year is mainly due to rainfall, which is extremely different in this area. Furthermore, there is a clear trend in the height and cover of vegetation depending on the time of non-use of fields. The highest height and lowest cover are for vegetation on the land that is not used for the shortest time (No35A-2 years). The height of the vegetation gradually decreases as the period of non-use increases. The highest vegetation cover was measured for vegetation on the land that has not been used for 3 years (No12 - 3 years). The vegetation cover is around $50 \%$ in other fields, and the differences are not statistically significant. The monitored vegetation parameters change during the succession. Initially, it is more of higher but thinner vegetation. In the following years, lower species with a similar degree of cover are more prevalent.

Differences can also be found in the weight of vegetation biomass. Most biomass is on the land that is not used for the shortest time (No35A 2 years). In other fields, the differences in biomass weight are significant. It can be assumed that biomass production is highest in the first years after leaving the fields. In the following years, there is probably a slowdown in production and decomposition; therefore, the amount of biomass does not decrease significantly.

The amount of biomass that remains on the soil surface represents the barrier and changes the environmental conditions. The changes in physical conditions can lead to a change in the species spectrum of vegetation as well as reduce water evaporation, runoff and wind erosion (Fowler,

Table 1. Characteristics of selected fields

\begin{tabular}{|c|c|c|}
\hline $\begin{array}{c}\text { Working } \\
\text { designation } \\
\text { of land }\end{array}$ & GPS coordinates & $\begin{array}{c}\text { Fallow period } \\
\text { in } 2018 \\
\text { (agricultural } \\
\text { non-use) }\end{array}$ \\
\hline No35A & $50.121139 \mathrm{~N} ; 66.833152 \mathrm{E}$ & 2 years \\
\hline No12 & $50.137272 \mathrm{~N} ; 66.794133 \mathrm{E}$ & 3 years \\
\hline No7 & $50.153063 \mathrm{~N} ; 66.776068 \mathrm{E}$ & 4 years \\
\hline No59 & $50.010139 \mathrm{~N} ; 66.995133 \mathrm{E}$ & 6 years \\
\hline
\end{tabular}



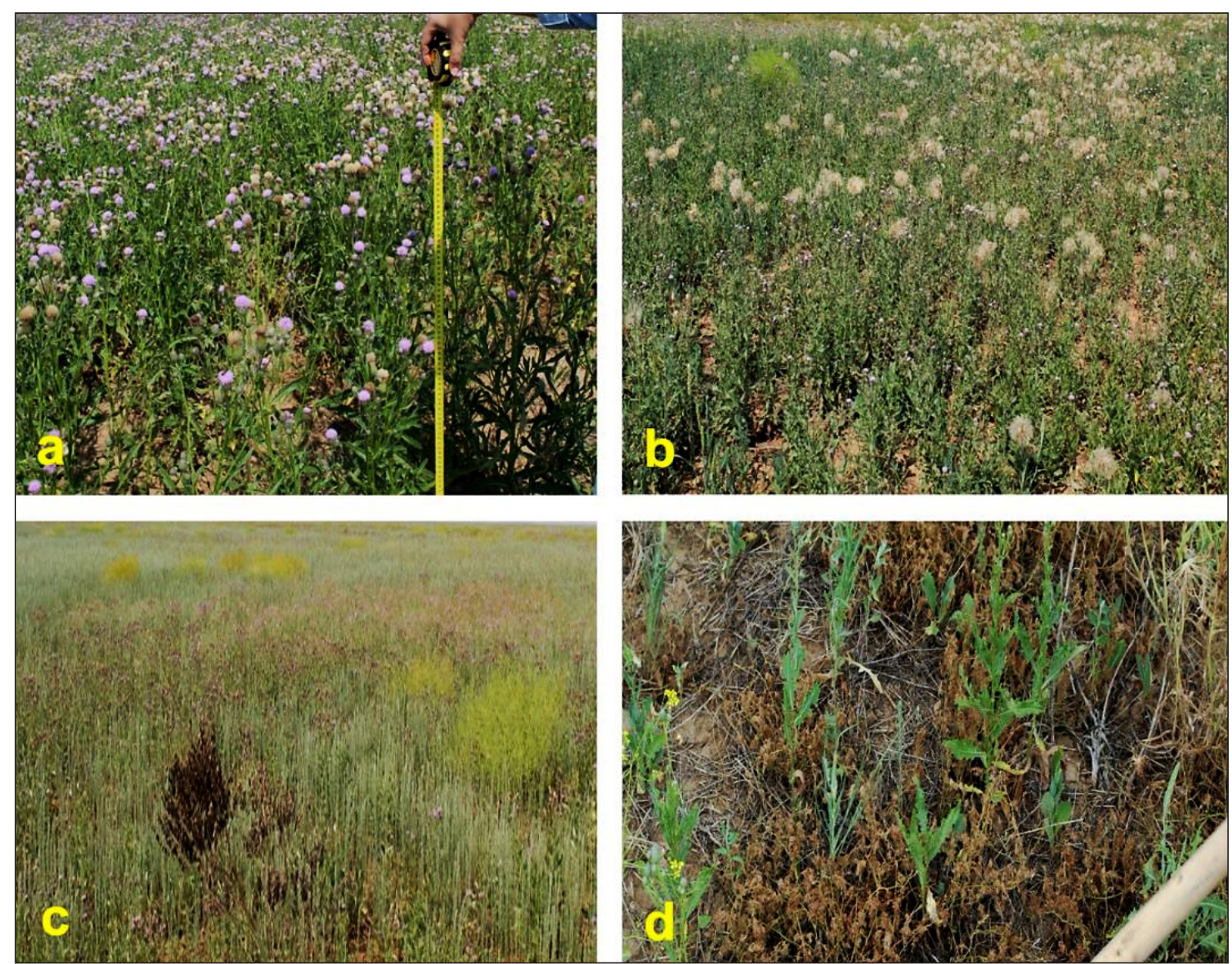

Figure 1. a) Vegetation on plot No35A -unused for 2 years b) Vegetation on plot No12 -unused for 3 years c) Vegetation on plot No7 - unused for 4 years d) Vegetation on plot No59-unused for 6 years

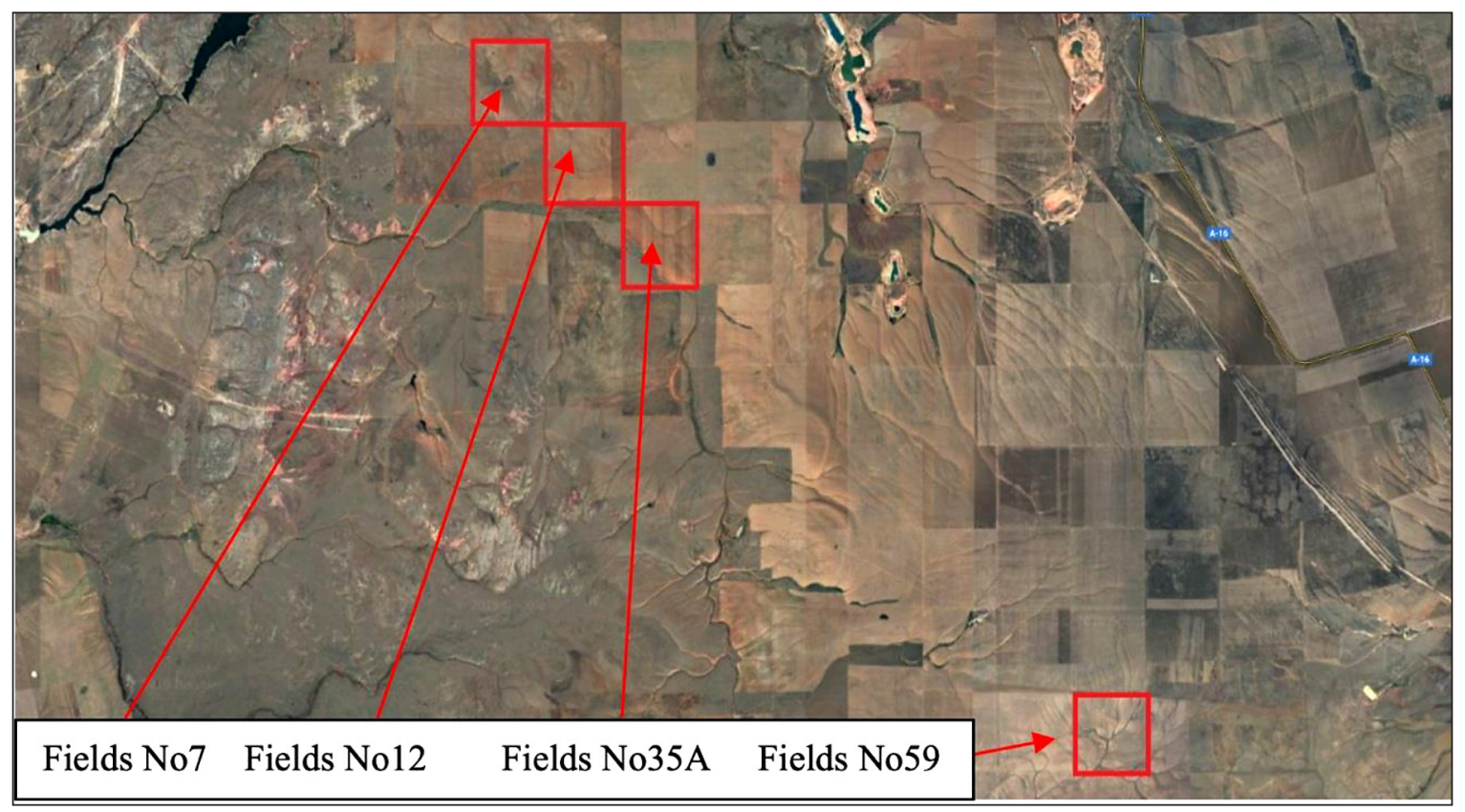

Figure 2. Location of monitored abandoned fields 
1986; Hamrick and Lee, 1987; Eckstein and Donath, 2005; Rotundo and Aguiar, 2005).

The changes in the species composition of vegetation were analyzed by means of the RDA method. Its results are statistically significant $(p=0.001)$. The results are shown in the ordination diagram (Fig. 3). Points show individual unused plots; vectors show plant species. The direction of the vector is determined by the predominant occurrence of the species on the land located in the direction of the vector.

Vegetation on the land, which is not used for the shortest time (No35A-2 years) was formed mainly by the Cirsium arvense (L.) Scop., Convolvulus arvensis L., Chenopodium album L. and a Triticum aestivum L. species. These are mainly species of originally grown crop and weeds. On the land which has not been used for 3 years (No12), there were mainly Ferula communis L. and a Tragopogon orientalis L. These are the original species and they reached the abandoned field from the surrounding lands. As far as the vegetation on the land that was not used for 4 years (No7) is concerned, there were significant species of Bassia prostrata (L.) Beck, Erysimum cheiranthoides L. and Lactuca tatarica (L.) C.A.Mey. Again, these are local native species. The dominant species on the land which has not been used for 6 years (No59), were Euphorbia stepposa Zoz ex Prokh. and a Tanacetum millefolium (L.) Tzvelev. These are also local native species.

The results of the species composition of vegetation indicate the progress of vegetation succession in abandoned fields under the conditions of Kastanozems. The vegetation here is relatively very poor in species throughout the observed period. This is in line with Aksoy et al., (2017) where the natural vegetation of the Kastanozem belt in western Turkey is dominated by short and poor grass vegetation which dries each summer. Similarly, in Mongolia Kastanozems are the most important soil where the vegetation changes to the central steppe and southern desert (Tamura et al., 2012). In the conducted study, annual species dominate in the first years, which subsequently give way to perennial dicotyledonous species. A common feature of these species is a deep root system (Díaz-Zorita et al., 2002; Wang et al., 2017; Kalinitchenko et al., 2021a; Kalinitchenko et al., 2021b), which allows them to obtain scarce water. According to Bonet (2004), the higher proportion of these perennial dicotyledonous species leads to higher production of above-ground

Table 2. Mean total coverage and the maximum height of the stand on the monitored unused fields

\begin{tabular}{|c|c|c|c|c|c|}
\hline \multirow{2}{*}{$\begin{array}{c}\text { Variant } \\
\text { No35A (2 years) }\end{array}$} & \multirow{2}{*}{$\begin{array}{l}\text { Year } \\
2018\end{array}$} & \multicolumn{2}{|c|}{$\begin{array}{l}\text { The mean maximum height }(\mathrm{m}) \text { and statistical } \\
\text { significance by Fisher's LSD test }\end{array}$} & \multicolumn{2}{|c|}{$\begin{array}{l}\text { Mean total coverage }(\%) \text { and } \\
\text { statistical significance according to } \\
\text { Fisher's LSD test }\end{array}$} \\
\hline & & 0.97 & b & 38.75 & $b, c$ \\
\hline No35A (2 years) & 2019 & 0.83 & $a, b, e$ & 33.75 & b \\
\hline No12 (3 years) & 2018 & 0.92 & $a, b$ & 63.75 & e \\
\hline No12 (3 years) & 2019 & 0.75 & $\mathrm{a}, \mathrm{d}, \mathrm{e}$ & 48.75 & a \\
\hline No7 (4 years) & 2018 & 0.85 & $a, b$ & 62.50 & $\mathrm{~d}, \mathrm{e}$ \\
\hline No7 (4 years) & 2019 & 0.68 & $c, d, e$ & 52.50 & a \\
\hline No59 (6 years) & 2018 & 0.63 & $c, d$ & 53.75 & $a, d$ \\
\hline No59 (6 years) & 2019 & 0.53 & c & 45.00 & $a, c$ \\
\hline
\end{tabular}

Note: Different indices mean statistical significance, the same indices mean statistical inconclusiveness at the level of significance $\mathrm{p}=0.05$.

Table 3. The average weight of phytomass on monitored unused fields

\begin{tabular}{|c|c|c|}
\hline Variant & \multicolumn{2}{|c|}{ Average weight of phytomass (t.ha ${ }^{-1}$ ) } \\
\hline No35A (2 years) & 2.50 & ${ }^{\mathrm{b}}$ \\
\hline No12 (3 years) & 1.80 & ${ }^{\mathrm{a}, \mathrm{b}}$ \\
\hline No7 (4 years) & 1.40 & ${ }^{\mathrm{a}}$ \\
\hline No59 (6 years) & 1.48 & ${ }^{\mathrm{a}, \mathrm{b}}$ \\
\hline
\end{tabular}

Note: Different indices mean statistical significance, the same indices mean statistical inconclusiveness at the level of significance $\mathrm{p}=0.05$. 


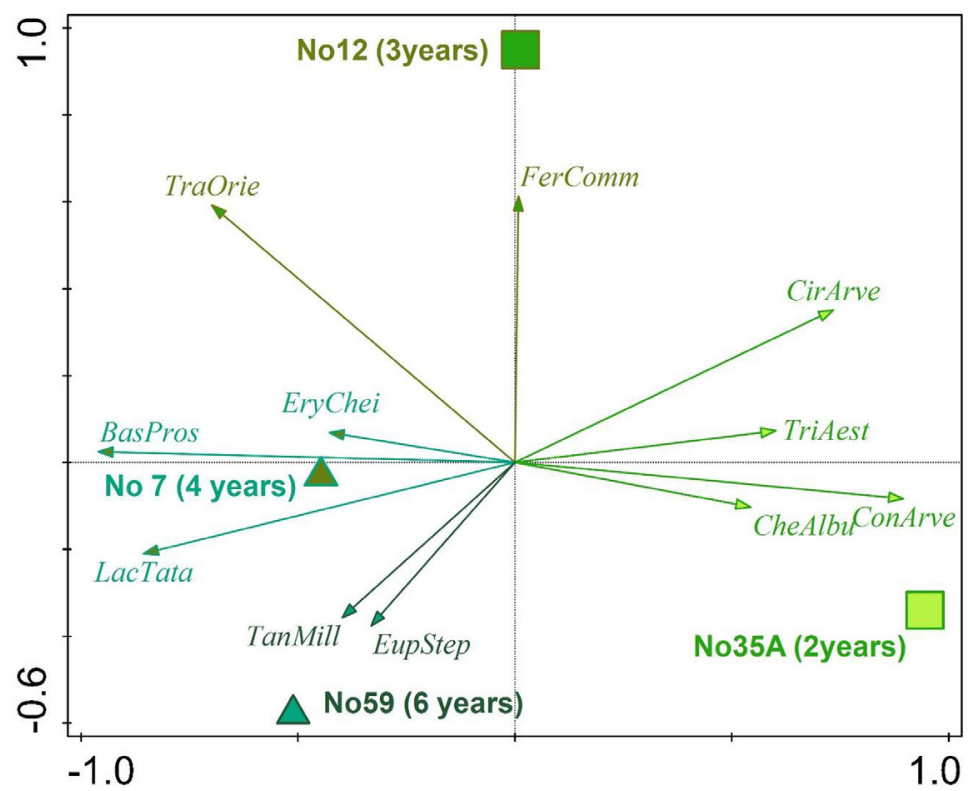

Figure 3. The ordination diagram expressing the relationship between plant species and unused land (Explanations of abbreviations: No35A (2years) - land unused for two years; No12 (3years) - land unused for three years; No 7 (4 years) - land not used for four years; No59 (6 years) - land not used for six years; Bas pros - Bassia prostrata (L.) Beck; Cir arve - Cirsium arvense (L.) Scop.; Con arve - Convolvulus arvensis L.; Ery chei - Erysimum cheiranthoides L.; Eup step - Euphorbia stepposa Zoz ex Prokh.; Fer comm - Ferula communis L.; Che albu - Chenopodium album L.; Lac tata - Lactuca tatarica (L.) C. A. Mey.; Tan millTanacetum millefolium (L.) Tzvelev; Tra orie - Tragopogon orientalis L.; Tri aest-Triticum aestivum L

biomass on abandoned land and thus limits the introduction of other species (grasses). The process of plant succession has a particular course in abandoned fields under the conditions of Kastanozems (Jiang et al., 2009; López-Vicente et al., 2011). Typical are low species diversity, slow changes in species composition and a high proportion of deep-rooted dicotyledonous species. Most of the species found, which dominate the fields after the third year after leaving the fields, produce above-ground biomass, which protects the soil surface and thus prevents erosion and soil degradation. However, these are species that are problematic in the event of a resumption of agricultural activity. The ecosystems in Central Asia with insufficient biodiversity and stability have been exposed in recent decades to a desertification process exacerbated by climate change (Han et al., 2016; Zhou et al., 2015; Lashchinsky et al., 2019). The changes in precipitation and temperature directly affect the soil water content and the retention function of the ecosystem (Sharratt et al., 2013). Abandoned fields inhabited by natural vegetation produce large amount of phytomass, hoping that it will reduce negative phenomena such as wind erosion and desertification in the areas with arid climates. The increase in phytomass is the basis for increasing soil fertility, which can be used to reuse land for agricultural purposes.

\section{CONCLUSIONS}

This study provides original data on the impact of human activity on vegetation under the specific conditions of Kastanozem from the Kostanay region (northern Kazakhstan). The efforts to maximize agricultural production have led to crop production even in arid areas. Subsequent social changes led to the gradual abandonment of these arid fields and left to their fate. Soil conditions and vegetation were changed by agricultural activity, so it was unclear how direction the succession of vegetation would occur. The vegetation of the abandoned fields is characterized by low species diversity. Succession runs from annual species to perennial species. However, it stops at a stage when perennial dicotyledonous species with a deep root system dominate. Even though the vegetation is species-poor with lower cover, it leaves a sufficient amount of biomass on the soil surface. This biomass protects Kastanozem from undesirable phenomena such as erosion and desertification process. 


\section{Acknowledgements}

This article is proactive. However, some of the data is indirectly related to a grant allocated by the Ministry of Education and Science of the Republic of Kazakhstan State Registration No.011RK00885.

\section{REFERENCES}

1. Aksoy E., Özsoy G., Karaata E.U., Boyraz D. 2018. Kastanozems. In: Kapur S., Akça E., Günal H. (eds). The Soils of Turkey. World Soils Book Series. Springer, Cham.

2. Anonym. 2016. Summary analytical report on the state and use of lands of the Republic of Kazakhstan for 2015. Ministry of Agriculture of the Republic of Kazakhstan, Astana. (in Russian).

3. Barrow C.J. 1991. Land Degradation. Cambridge University Press, Cambridge.

4. Bonet A. 2004. Secondary succession of semi-arid Mediterranean old-fields in south-eastern Spain: insights for conservation and restoration of degraded lands. J. Arid Environ, 56(2), 213-233.

5. Cremene C., Groza G., Rakosy L., Schileyko A.A., Baur A., Erhardt A., Baur B. 2005. Alterations of steppe-like grasslands in Eastern Europe: a threat to regionalbiodiversity hotspots. Conservation Biology, 19, 1606-1618.

6. Davidson E.A., Carvalho C.J.R., Figueira A.M., Ishida F.Y., Ometto J.P.H., Nardoto G.B., Sab'a R.T., Hayashi S.N., Leal E.C., Guimar aes Vieira I.C., Martinelli L.A. 2007. Recuperation of nitrogen cycling in Amazonian forests following agricultural abandonment. Nature, 447, 995-998.

7. Díaz-Zorita M., Duarte G.A., Grove J.H. 2002. A review of no-till systems and soil management for sustainable crop production in the subhumid and semiarid Pampas of Argentina. Soil and Tillage Research, 65(1), 1-18.

8. Dudiak N.V., Pichura V.I., Potravka L.A., Stroganov A.A. 2020. Spatial Modeling of the Effects of Deflation Destruction of the Steppe Soils of Ukraine. Journal of Ecological Engineering, 21(2), 166-177.

9. Eckstein R.L. \& Donath T.W. 2005. Interactions between litter and water availability affect seedling emergence in four familial pairs of floodplain species. Journal of Ecology, 93, 807-816.

10. Enyedi Z.M., Ruprecht E., Deák M. 2008. Longterm effects of the abandonment of grazing on steppe-like grasslands. Applied Vegetation Science, $11,53-60$.

11. Espolov T.I. 2002. The effectiveness of the agri-food complex of Kazakhstan. Agricultural University.
Almaty.

12. Fleskens L., Stringer L.C. 2014. Land management and policy responses to mitigate desertification and land degradation. Land Degrad, 25(12), 1-4.

13. Fowler N.L. 1986. Microsite requirements for germination and establishment of three grass species. American Midland Naturalist, 115, 131-145.

14. Frühauf M., Meinel T., Schmidt G. 2020. The Virgin Lands Campaign (1954-1963) Until the Breakdown of the Former Soviet Union (FSU): With Special Focus on Western Siberia. In: Frühauf M., Guggenberger G., Meinel T., Theesfeld I., Lentz S. (Eds.). Kulunda: Climate Smart Agriculture, Innovations in Landscape Research. Springer International Publishing, 101-118.

15. Hamrick J.L. \& Lee J.M. 1987. Effect of soil surface topography and litter cover on the germination, survival, and growth of musk thistle (Carduus nutans). American Journal of Botany, 74, 451-457.

16. Han Q., Luo G., Li C., Shakir A., Wu M., Saidov A. 2016. Simulated grazing effects on carbon emission in Central Asia. Agricult. Forest Meteorol, 216, 203-214.

17. Hu Y., Hana Y., Zhanga Y. 2020. Land desertification and its influencing factors in Kazakhstan. Journal of Arid Environments, 180, 104-203.

18. IUSS Working Group WRB. 2015. World Reference Base for Soil Resources 2014, update 2015 International soil classification system for naming soils and creating legends for soil maps. World Soil Resources Reports, FAO, Rome, 106.

19. Jiang J.P., Xiong Y.C., Jiang H.M., Ye D.Y., Song Y.J., Li F.M. 2009. Soil Microbial Activity During Secondary Vegetation Succession in Semiarid Abandoned Lands of Loess Plateau. Pedosphere, 19(6), 735-747.

20. Kalinichenko V.P. 2015. Creation of the Botanical Gardens Soil Improvement, Nutrition and Irrigation System Based on the Biogeosystem Technique methodology. The Role of Botanic Gardens in the Conservation and Monitoring of Biodiversity. The Collection of Materials of the International Scientific Conference Devoted to the 100th Anniversary of the Southern Federal University. 27-30 May 2015 Rostov on Don. Southern Federal University Publishing House, 50-54.

21. Kalinitchenko V.P., Glinushkin A.P., Sharshak V.K., Ladan E.P., Minkina T.M., Sushkova S.N., Mandzhieva S.S., Batukaev A.A., Chernenko V.V., Ilyina L.P., Kosolapov V.M., Barbashev A.I., Antonenko E.M. 2021a. Intra-Soil Milling for Stable Evolution and High Productivity of Kastanozem Soil. Processes, 9, 1302.

22. Kalinitchenko V.P., Glinushkin A.P., Swidsinski A.V., Minkina T.M., Andreev A.G., Mandzhieva S.S., Sushkova S.N., Makarenkov D.A., Ilyina L.P., 
Chernenko V.V., Zamulina I.V., Larin G.S., Zavalin A.A., Gudkov S.V. 2021b. Thermodynamic mathematical model of the Kastanozem complex and new principles of sustainable semiarid protective silviculture management. Environmental Research, 194, 110605.

23. Kanchikerimath M. \& Singh D. 2001. Soil organic matter and biological properties after 26 years of maize-wheat-cowpea cropping as affected by manure and fertilization in a Cambisol in semiarid region of India. Agric. Ecosyst. Environ., 86(2), $155-162$.

24. Kazangapova N.B., Abeuova S.M., Romanova S.M., Satova K.M. 2017. Soils of the Karagandy forest nursery: The basis of environmental and aesthetic landscapevalue of the region. News of the National Academy of Sciences of the Republic of Kazakhstan. Series of Geology and Technical Sciences, 6(426), 150-156.

25. Kirichenko-Babko M., Danko Y., Franus M., Stępniewski W. 2020. Effect of Soil Moisture on the Epigeic Arthropods Diversity in Steppe Landscape. J. Ecol. Eng., 21(5), 137-147.

26. Klatka S. 2020. Soil Productivity Index in the Selected Area of Post-Mining Geomechanical Deformations. Journal of Ecological Engineering, 21(5), 148-154.

27. Klein I., Gessner U., Kuenzer C. 2012. Regional land cover mapping and change detection in Central Asia using MODIS time-series. Appl. Geogr., 35, 219-234.

28. Kouba Y., Gartzia M., El Aich A., Alados C.L. 2018. Deserts do not advance, they are created: Land degradation and desertification in semiarid environments in the Middle Atlas, Morocco. Journal of Arid Environments, 158, 1-8.

29. Kučera J., Podhrázská J., Karásek P., Papaj V. 2020. The Effect of Windbreak Parameters on the Wind Erosion Risk Assessment in Agricultural Landscape. Journal of Ecological Engineering, 21(2), 150-156.

30. Lashchinsky N.N., Tishenko M.P., Korolyuk A. 2019. Quantitative analysis of local cenoflora of the steppe zone of Northern Kazakhstan. Bulletin of Tomsk state University. Biology, 45, 69-90.

31. Li H.B., Han X.Z., Qiao Y., Hou X.Y., Xing B.S. 2009. Carbon dioxide emission from black soil as influenced by land-use change and long-term fertilization. Commun. Soil Sci. Plant Anal., 40, 1350-1368.

32. Li J., Ma X., Zhang C. 2020. Predicting the spatiotemporal variation in soil wind erosion across Central Asia in response to climate change in the 21 st century. Science of the Total Environment, 709, 136060 .

33. López-Vicente M., Lana-Renault N., García-Ruiz J.M. 2011. Assessing the potential effect of different land cover management practices on sediment yield from an abandoned farmland catchment in the Spanish Pyrenees. J. Soils Sediments, 11, 1440-1455.

34. Nyussupova G.N., Tokbergenova A.A., Kairova S.G., Arslan M. 2015. Mechanisms of the formation of ecologically-oriented agricultural land use in Kazakhstan. Oxidation Communications, 38(2), 886-899.

35. Pimentel D., Harvey C., Resosudarmo P., Sinclair K., Kurz D., McNair M., Crist S., Shpritz L., Fitton L., Saffouri R., Blair R. 1995. Environmental and economic costs of soil erosion and conservation benefits. Science, 267, 1117-1123.

36. Prishchepov A.V., Schierhorn F., Dronin N., Ponkina E.V., Müller D. 2020. 800 Years of Agricultural Land-use Change in Asian (Eastern) Russia. In: Frühauf M., Guggenberger G., Meinel T., Theesfeld I., Lentz S. (Eds.) Kulunda: Climate Smart Agriculture, Innovations in Landscape Research. Springer International Publishing, 67-87.

37. Qin C., Tang Y., Chen J., Chen X. 2020. The impact of soil and water resource conservation on agricultural production: an analysis of the agricultural production performance in Zhejiang, China. Agricultural Water Management, 240, 106268.

38. Rachkovskaya E.I. \& Bragina T.M. 2012. Steppes of Kazakhstan: Diversity and Present State. In: Werger MJA., van Staalduinen MA. (Eds.). Eurasian Steppes. Ecological Problems and Livelihoods in a Changing World, Plant and Vegetation. Springer, Netherlands, Dordrecht, 103-148.

39. Richard T.C., Keith P., Edward T.E., 2001. Grassland management and conversion into grassland: effects on soil carbon. Ecol. Appl, 11(2), 343-355.

40. Rotundo J.L. \& Aguiar M.R. 2005. Litter effects on plant regeneration in arid lands: acomplex balance between seed retention, seed longevity and soil-seed contact. Journal of Ecology, 93, 829-838.

41. Schwieger D.A.M. \& Mbidzo M. 2020. Socio-historical and structural factors linked to land degradation and desertification in Namibia's former Herero 'homelands'. Journal of Arid Environments, 178, 104151.

42. Sharratt B.S., Vaddella V.K., Feng G. 2013. Threshold friction velocity influenced by wetness of soils within the Columbia Plateau. Aeolian Res., 9, 175-182.

43. Shen Y., Zhang C., Wang X., Zou X., Kang L. 2018. Statistical characteristics of wind erosion events in the erosion area of Northern China. CATENA, 167, 399-410.

44. Shevyrnogov A.P., Shpedt A.A., Larko A.A., Botvich I.Y., Emelyanov D.V., Pisman T.I. 2019. Identification of unused agricultural lands (deposits and fields under steam) by ground-based spectrometric data. Regional systems for integrated remote sensing 
of agrolandscapes. Materials of 2 All-Russian scientific and practical seminar. Krasnoyarsk.

45. Tamura K., Asano M., Jamsran U. 2013. Soil Diversity in Mongolia. In: Yamamura N., Fujita N., Maekawa A. (eds). The Mongolian Ecosystem Network. Ecological Research Monographs. Springer, Tokyo.

46. Uspanov U.U., Yevstifeyev U.G., Storozhenko D.M., Lobova E.V. 1975. Soil Map of the Kazakh SSR 1:2.500.000. Kazakh SSR. Ałma-Ata. (in Russian)

47. Vesterdal L., Ritter E., Gundersen P. 2002. Change in soil organic carbon following afforestation of former arable land. For. Ecol. Manage., 169, 137-143.

48. Wang Z.Y., Hou J., Qu Z.Q., Guo J.Y., Li J.R. 2017. Root distribution of 430 plants in temperate grassland of northern china. Applied Ecology Andenvironmental Research, 15(3), 1625-1651.
49. Wijitkosum S. 2021. Factor influencing land degradation sensitivity and desertification in a drought prone watershed in Thailand. International Soil and Water Conservation Research, 9(2), 217-228.

50. Xi X. \& Sokolik I.N. 2016. Quantifying the anthropogenic dust emission from agricultural land use and desiccation of the Aral Sea in Central Asia. J. Geophys. Res. Atmos., 121, 270-281.

51. Zhang H., Peng J., Zhao C., Xu Y., Dong J., Gao Y. 2021. Wind speed in spring dominated the decrease in wind erosion across the Horqin Sandy Land in northern China. Ecological Indicators, 127, 107599.

52. Zhou Y., Zhang L., Fensholt R., Wang K., Vitkovskaya I., Tian F. 2015b. Climate Contributions to Vegetation Variations in Central Asian Drylands: Pre- and Post-USSR Collapse. Rem. Sens., 7, 2449-2470. 